\title{
Weakened Patient Loyalty Model at Beauty Clinics:Based on Variety Seeking Behavior, Dissatisfaction, Negative WOM and Brand Switching
}

\author{
Herni Justiana Astuti ${ }^{1 *}$ and Suryo Budi Santoso ${ }^{1}$ \\ ${ }^{1}$ Universitas Muhammadiyah Purwokerto
}

\begin{abstract}
The purpose of this study was to design the Weakened Loyalty model through Variety Seeking Behavior, Dissatisfaction, Negative WOM and Brand Switching. The sample in this study was a patient of a beauty clinic who did treatment for one year or more and had moved from another clinic. The sample used was 173 respondents. Data analysis using Structural Equation Modeling with PLS approach. The data meets convergent validity and composite reliability. The results of the analysis prove that negative WOM, variety seeking behavior and dissatisfaction are factors that have the potential to weaken loyalty, because these three variables have a significant direct effect on brand switching. However, it does not directly affect patients to really weaken loyalty. Dissatisfaction can mediate relationship between Negative WOM and Brand Switching.
\end{abstract}

Keywords: Patient Loyalty, Variety Seeking Behavior, Dissatisfaction, Negative WOM and Brand Switching

\section{Introduction}

Competition in the business world in the modern era is undergoing many changes. Companies in any form look for the right strategy to reach the best position in the minds of consumers. One example is the competition in the beauty clinics in Indonesia. The development of a fast-growing beauty trend also affects the tastes of beauty products. Beauty that is identified with women, makes them try to look attractive not only fulfills the need for a beautiful face, but also attractive body and skin care. Nowadays there are more and more places of beauty clinics with various choices that suit customer needs and even dare to give promises about the desired beauty criteria.

Customer loyalty is absolutely needed by a company to be able to survive and be able to compete with other companies. To build customer loyalty, there is a need for companies to continue to provide the best quality in each product or service they have. Satisfied and loyal customers are opportunities to get new customers. Maintaining all existing customers will generally be more profitable than customer changes because the cost of attracting new customers can be five times the cost of retaining an existing customer (Kotler and Keller, 2009).

In today's increasingly competitive world, the word "loyal customers" is very rare. Due to the fact in the field there is no evidence that shows that there are consumers who are truly loyal to one particular brand. The average person must have consumed different brands in one category. One reason is post-purchase dissatisfaction. The greater customer

\footnotetext{
* Corresponding Author: +6289675955925

Email address: herni99@gmail.com
} 
dissatisfaction, the more likely they are to switch providers, complain, and discuss their dissatisfaction with others (Zeelendberg and Pieters, 2004). Halstead (2002) supports the findings of previous researchers, that dissatisfied consumers significantly involved more word-of-mouth behavior than satisfied consumers, and would tell more people about their unsatisfactory experiences. Baird (2000) added that dissatisfied customers will tell 13 other people. Suharseno et al. (2013) explained that brand shifts carried out by consumers were caused by variations in search. The variety seeking behavior can be caused by boredom in product attributes. Consumers will be very easily affected when faced with a variety of brands that provide the desired product, causing consumers to be loyal to one brand. Based on the findings of Astuti and Nagase (2016), loyalty is prone to erosion when a patient decides to try treatment elsewhere receive negative information about service performance. These events can result in reduction or elimination of loyalty, and patients can switch to other service providers.

Based on the description above, researchers consider it important research to design models that cause customer loyalty to be weak. Is the decision to switch brands, dissatisfaction, variation seeking behavior, and talk from mouth to mouth causing loyalty to be weak? The results of the study can be a reference for beauty clinics to anticipate the causes of erosion of consumer loyalty. The purpose of this study is to design a model that weakens loyalty in terms of brand switching decisions, dissatisfaction, variation seeking behavior, and word of mouth conversation.

\section{Literatures Review and Hypothesis}

\subsection{Patient Loyalty}

Basically loyalty is the behavior of consumers to continue to use products or services and are based on attitudes towards products or services. The difference between loyal use and habits relates to the dynamics underlying the selection of a particular product or service. A loyal buyer, at some level, is involved in a relationship, while habitual buyers are indifferently involved in routine behavior (Knox, 1998). Dick and Basu (1994) treat the concept of customer loyalty as a relationship between one's attitude towards an entity (brand, service, shop, and vendor) and someone's patronage behavior. Customer loyalty is also determined by consumer characteristics. For example, some people don't like uncertainty and are very loyal to the first product they use. Others are more "adventurous" and want to try new products even though they like or are satisfied with the previous product.

\subsection{Brand Switching}

Brand switching is a condition in which a consumer moves his loyalty and switches to a competitor's brand and stops using his old product. Brand switching behavior is a complex phenomenon carried out by consumers for certain reasons. The vulnerability of consumers to continue consuming one brand can occur because of post-consumption dissatisfaction (Thawil, 2014), the existence of behavior seeking variation due to boredom or wanting to try other products (Arundina, 2016) or incessant negative talk by word of mouth (Kartajaya and Ridwansyah, 2012).

From the description above, the hypothesis can be drawn:

H1: Brand Switching has a significant negative effect on loyalty 


\subsection{Dissatisfaction}

Consumer dissatisfaction occurs when the performance of a product is not in accordance with the perceptions and expectations of consumers (Kotler and Keller, 2009: 172). Consumers who experience service failure will react in various ways. According to Zeithaml et al (2012) that consumers have two ways to react; active and passive. Consumers who are passive do not react to complain, maybe because they do not know how to complain, or because they do not believe that the complaint submitted will be responded positively. Those who will actively react otherwise, he makes a complaint directly to the service provider, will disseminate his dissatisfaction to others for various reasons, he even uses a third party. All reactions, whether passive or active leads to the same goal: they leave or switch to another provider, or remain loyal to the product. Wangenheim and Bayon (2004) found that $68.9 \%$ of respondents were predicted to remain loyal or switch. One consideration is satisfaction. Dissatisfied consumers will switch brands (Yunita and Rosa, 2016; Andriani and Untarini, 2015; Astuti and Nagase, 2014), while satisfied consumers will remain loyal (Astuti and Nagase, 2014; Astuti and Nagase, 2016).

From the description above, the hypothesis can be drawn:

H2: Dissatisfaction has a significant positive effect on brands switching

H3: Dissatisfaction has significant negative affect on loyalty

\subsection{Variety Seeking Behavior}

Variation seeking behavior is the behavior of consumers who try to find brand diversity outside their habits because the level of involvement of some products is low. This behavior often occurs in some products with a low level of involvement. According to Assael in Waluyo (2003), said this behavior tends to occur at the time of the purchase of a product that raises minimal risks borne by consumers and when consumers lack commitment to certain brands. Variety seeking behavior arises when consumers feel fulfilled or are bored with the characteristics of products consumed before. The variety seeking behavior can be caused by boredom in the product. Consumers will be very easily affected if faced with a variety of brands that provide the desired product so that consumers are not loyal to one brand only.

From the description above, the hypothesis can be drawn:

H4: Variety seeking behavior has a significant positive effect on brand switching

H5: Variety seeking behavior has a significant negative effect on loyalty

\subsection{Negative Word-of-mouth}

Word of mouth is defined by Lau and $\mathrm{Ng}$ (2001) as verbal, person-to-person communication between what non-commercial communicators and recipients feel, about brands, products, or services offered for sale. Negative Word of Mouth is the act of giving consumers negative information to other consumers from someone to another (interpersonal) non-commercial both brands, products and services (Hasan, 2010). Previous research Harrison-Walker (2001) in Padmalia (2018) shows that every satisfied customer will tell 3-5 other people about his experience, while those who are dissatisfied will tell 1011 people. This shows that consumers often tell dissatisfaction with products rather than satisfaction. Therefore, the company needs to pay attention to the negative transmittal about the company which will ultimately influence product purchasing decisions and brand switching (Kartajaya and Ridwansyah, 2012).

From the description above, the hypothesis can be drawn:

H6: Negative Word of mouth have a significant positive effect on brands switching 
H7: Negative Word of mouth have a significant positive effect on dissatisfaction

H8: Negative Word of mouth have a significant negative effect on loyalty

\subsection{Brand switching and Dissatisfaction as intervening variables that weakens loyalty}

Brand switching is the consumer's decision to switch and use other product brands. Consumer decisions can be due to consumer behavior that is easily bored, and wants to try new products (Arundina, 2016). Brand switching can also be due to post-purchase consumer dissatisfaction (Yunita and Rosa, 2016). In addition, consumers decide to switch brands can be caused by negative word of mouth. The antecedents of switching brands cause consumers to be no longer loyal.

From the description above, the hypothesis can be drawn:

H9: Brand switching mediates the relationship between negative word-of mouth, variety seeking and dissatisfaction to loyalty

H10: Dissatisfaction mediates the relationship between negative word-of mouth to brand switching and loyalty

\section{Research Method}

\subsection{Data Analysis}

Data were analyzed using structural equation modeling with a partial least square approach.

\subsection{Measures}

PLS-SEM analysis usually consists of two sub-models, namely the measurement model or often called the outer model and the structural model or often called the inner model. Evaluation of models using SmartPLS 3.0 can be done by assessing the results of measurement models, namely through confirmatory factor analysis (CFA) by testing the validity and reliability of latent constructs (see table 1 ). Then proceed with the evaluation of structural models and significant testing to test the influence between constructs or variables.

Table 1. Rule of Thumb Evaluation of the Measurement Model (Gozhali and Latan, 2015)

\begin{tabular}{|c|c|c|}
\hline $\begin{array}{c}\text { Validity and } \\
\text { Reliability }\end{array}$ & Parameter & Rule of Thumb \\
\hline \multirow{3}{*}{ Convergent Validity } & Loading Factor & $\begin{array}{c}1 .>0.70 \text { for Confirmatory Research } \\
2.0 .50-0.60 \text { is still acceptable for the initial } \\
\text { stages of development }\end{array}$ \\
\cline { 2 - 3 } & $\begin{array}{c}\text { Average Variance } \\
\text { Extracted (AVE) }\end{array}$ & $\begin{array}{c}>0.50 \text { for Confirmatory and Exploratory } \\
\text { Research }\end{array}$ \\
\hline \multirow{2}{*}{ Reliability } & $\begin{array}{c}\text { Composite } \\
\text { Reliability }\end{array}$ & $\begin{array}{c}1 .>0.70 \text { for Confirmatory Research } \\
2 .>0.60 \text { is still acceptable for the initial } \\
\text { stages of development }\end{array}$ \\
\hline
\end{tabular}

Furthermore, after the outer model meet the criterias, the inner model was tested. 


\section{Findings}

The response rate for the questionnaire was $96.1 \%$. The total number of respondents was 173 , they were patients at a beauty clinic who had changed services and were currently taking care for 1 year in the current beauty clinic.

\subsection{Outer Model}

A measurement model can proceed to the inner model stage if it meets valid and reliable criteria. It can be seen that table 2 describes a measurement model. All indicators are acceptable because loading factors are greater than 0.5. Likewise with AVEs, all variables meet the criteria for Convergent Validity which is greater than 0.5. So all indicators and variables are valid. The model is said to be reliable if the value of Composite Reliability is more than 0.6. If seen in table 2 , all variables have met reliable criteria.

Table 2. Variables, Indicators, Loading Factor, AVE and Composite Reliability

\begin{tabular}{|c|c|c|c|c|}
\hline Variables & Indicators & $\begin{array}{l}\text { Loading } \\
\text { Factors }^{\mathrm{a}}\end{array}$ & $\mathrm{AVEs}^{\mathrm{b}}$ & $\begin{array}{l}\text { Composite } \\
\text { Reliability }^{\mathrm{c}}\end{array}$ \\
\hline Loyalty & Firmness (L1) & 0.912 & \multirow{3}{*}{0.699} & \multirow{3}{*}{0.874} \\
\hline \multirow[t]{2}{*}{ (Astuti dan Nagase, 2014) } & Defense (L2) & 0.745 & & \\
\hline & Repeat purchases (L3) & 0.842 & & \\
\hline Brand Switching & Dissatisfaction (BS1) & 0.846 & \multirow{3}{*}{0.590} & \multirow{3}{*}{0.811} \\
\hline \multirow[t]{2}{*}{ (Astuti dan Nagase, 2014) } & Variation seeking (BS2) & 0.785 & & \\
\hline & Negative WOM (BS3) & 0.663 & & \\
\hline \multirow{3}{*}{$\begin{array}{l}\text { Variaety Seeking Behavior } \\
\text { (Priansa, 2016) }\end{array}$} & Differences between brands (VSB1) & 0.826 & \multirow{3}{*}{0.553} & \multirow{3}{*}{0.781} \\
\hline & Bored (VSB2) & 0.847 & & \\
\hline & Just want to try (VSB3) & 0.510 & & \\
\hline \multirow{4}{*}{$\begin{array}{l}\text { Negative-WOM } \\
\text { (Hasan, 2010) }\end{array}$} & Mutual dialogue.(WOM1) & 0.639 & \multirow{4}{*}{0.597} & \multirow{4}{*}{0.853} \\
\hline & Pass along effect (WOM2) & 0.863 & & \\
\hline & Knowledge diffusion (WOM3) & 0.876 & & \\
\hline & Cause and effect (WOM4) & 0.684 & & \\
\hline \multirow[t]{3}{*}{ Dissatisfaction } & Bad treatment experience (DS1) & 0.809 & \multirow{3}{*}{0.684} & \multirow{3}{*}{0.866} \\
\hline & Disappointed (DS2) & 0.841 & & \\
\hline & Not recommend to others (DS3) & 0.830 & & \\
\hline
\end{tabular}

AVE: Average Varian Extract

${ }^{a}$ Acceptable value of Loading Factor is greater than 0.5

${ }^{\mathrm{b}}$ Acceptable value of AVE is greater than 0.5

${ }^{\mathrm{c}}$ Acceptable value of Composite Reliability is greater than 0.6

\subsection{Inner Model}

Evaluation of structural models or inner models aims to predict relationships between latent variables. The inner model is evaluated by looking at the magnitude of the percentage variance described, namely by looking at the R-Square value for the endogenous latent construct. Based on Figure 1, it can be seen that Negative WOM can explain the relationship with Dissatisfaction of $24.7 \%$. Whereas Negative WOM, Variety Seeking Behavior and Dissatisfaction can explain the relationship with Brand Switching at $47.1 \%$. Then, Loyalty is explained by all latent variables of $11.7 \%$. 


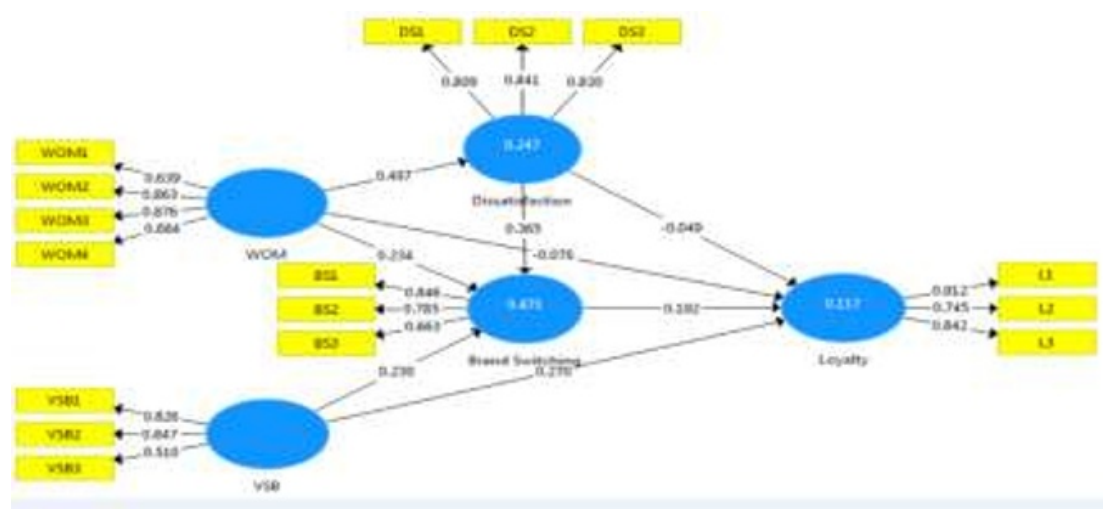

Figure 1. Structural Equation Modeling of Loyalty in Beauty Clinics

Based on the literature review that builds the hypothesis, 10 main hypotheses are obtained. Table 3 explains the results of the relationship, path coefficient, and $\mathrm{P}$ Value. Of the 10 hypotheses, there are 4 hypotheses received from the relationship of direct influence and 1 hypothesis received from the relationship of indirect influence. The relationship of variety seeking behavior with loyalty has a significant effect, but the direction of the relationship is positive. While the hypothesis is a significant negative effect, therefore the hypothesis is Potentially Weakens Loyalty

Table 3. Relationships, Path Coefficients, P Values, Result

\begin{tabular}{llll}
\hline Relationships & $\begin{array}{l}\text { Path } \\
\text { Coefficients }\end{array}$ & P values & Results \\
& 0.192 & 0.086 & Rejected \\
\hline Brand Switching $\rightarrow$ Loyalty (H1) & 0.365 & 0.000 & Acceptable \\
Dissatisfaction $\rightarrow$ Brand Switching (H2) & -0.049 & 0.628 & Rejected \\
Dissatisfaction $\rightarrow$ Loyalty (H3) & 0.230 & 0.002 & Acceptable \\
Variety Seeking Behavior $\rightarrow$ Brand Switching (H4) & 0.270 & 0.007 & Rejected \\
Variety Seeking Behavior $\rightarrow$ Loyalty (H5) & 0.234 & 0.002 & Acceptable \\
Negative WOM $\rightarrow$ Brand Switching (H6) & 0.497 & 0.000 & Acceptable \\
Negative WOM $\rightarrow$ Dissatisfaction (H7) & -0.076 & 0.384 & Rejected \\
Negative WOM $\rightarrow$ Loyalty (H8) & 0.045 & 0.119 & Rejected \\
Negative WOM $\rightarrow$ Brand Switching $\rightarrow$ Loyalty (H9a) & 0.044 & 0.187 & Rejected \\
Variety seeking $\rightarrow$ Brand Switching $\rightarrow$ Loyalty (H9b) & 0.070 & 0.110 & Rejected \\
Dissatisfaction $\rightarrow$ Brand Switching $\rightarrow$ Loyalty (H9c) & 0.181 & 0.000 & Acceptable \\
Negative WOM $\rightarrow$ Dissatisfaction $\rightarrow$ brand switching (H10a) & 0.10 .025 & 0.643 & Rejected \\
Negative WOM $\rightarrow$ Dissatisfaction $\rightarrow$ Loyalty (H10b) & -0.025 & & \\
\hline
\end{tabular}

\section{Discussion}

Based on the theoretical building described earlier in this paper, factors that can weaken loyalty are brand switching, dissatisfaction, negative WOM and variety seeking behavior. However, some hypothesis test results are different.

\subsection{Potentially Weakens Loyalty}

A patient has switched brands from a previous clinic because of their behavior, which is easily bored and might like to try new products, in fact makes them loyal to the beauty clinic they are currently using in the past year. A patient who experiences post-purchase dissatisfaction will weaken loyalty, but this relationship does not significantly weaken 
loyalty. This relationship also occurs due to negative WOM towards loyalty. Beauty clinic patients who have the potential to switch brands because of getting negative information, due to their adventurous behavior and dissatisfaction, apparently do not significantly affect loyalty.

In theory, these three variables make loyalty weak and have the potential to switch products or services. This has indeed happened to beauty clinics before, they have switched brands to beauty clinics now and for the past year or more they are still doing maintenance and buying products at the current beauty clinic. Beauty clinic service providers must be aware of their potential to move.

\subsection{Really Weakens Loyalty}

Loyalty is weak when the desire for brand switching arises. The desire to move can be seen from the incessant negative information received by patients from word of mouth, patients who are easily bored and have the desire to try other products, or unpleasant experiences. These three variables directly have a significant effect on switching brands, even negative information received causes patients to begin to feel dissatisfied and to compare actual expectations with the performance of beauty clinics.

\section{Conclusions and Managerial Implication}

\subsection{Conclusions}

A service company such as a beauty clinic continues to strive for its strategy to have loyal customers. Negative WOM, variety seeking behavior and dissatisfaction are factors that have the potential to weaken loyalty, because these three variables have a significant direct effect on brand switching. However, it does not directly affect patients to really weaken loyalty.

\subsection{Managerial Implication}

Respondents of this study were those who moved from the previous beauty clinic and now they are still at least 1 year of care at the current beauty clinic. The factors that cause loyalty are weak and the potential for brand switching must be the concern of beauty clinic managers. Customers feel comfortable and suitable for doing treatment at the current beauty clinic, but when they get unpleasant experiences they have the potential to move. Therefore beauty clinics must strive so that when they connect with the clinic, they must be satisfied. Managers must also anticipate dissatisfied consumers because they have the potential to share their negative experiences with potential customers. Likewise, to deal with consumers who get bored quickly, managers also try to innovate attractive care packages so as to minimize customers to switch brands.

\section{References}

Arundina, Debora Ocvia., Sriwidodo, Untung., and Wibowo, Edi. (2016) Influence Analysis of Prices, Product Quality, Variety Seeking Behavior And Product Competitor Toward Brand Switching Decision in Charm Women's Consumers. Jurnal Ekonomi dan Kewirausahaan Vol. 16 (Special edition): 132 -142 (In Indonesian) 
Astuti, HJ dan Nagase. K (2016). A framework for conceptualizing patient loyalty to healthcare organizations. Health Services Management Research.Vol. 29(3) 70-78.

Dick AS and Basu K. Customer loyalty: Toward an integrated conceptual framework. J Acad Market Sci 1994; 22(2): 99-113

Gozhal

i, Imam., dan Latan, Hengky. (2015). PARTIAL LEAST SQUARE Konsep, Teknik dan Aplikasi Menggunakan Program SmartPLS 3.0. Semarang: Undip (In Indonesian)

Halstead D. Negative word of mouth: Substitute for or supplement to consumer complaints? J Consum Satisf DissatisfComplain Behav 2002; 15: 1-12

Hasan, Ali (2010). Word of Mouth Marketing. Medpress, Yogyakarta (In Indonesian)

Kartajaya, H., \& Ridwansyah, A. (2012). Service with Character, Jakarta: PT Gramedia Pustaka Utama (in Indonesian)

Knox, Simon. (1998). Loyalty-based segmentation and the customer development process. European Management Journal, 16(6), 729-737

Kotler, Philip dan Lane, Keller, Kevin. 2009. Marketing Management. Penerbit Erlangga (In Indonesian)

Lau GTand Ng S. Individual and situational factors influencing negative word-of-mouth behaviour. Can J Admin Sci 2001; 18(3): 163-178

Padmalia, M. (2018). Determinants of Decisions in Purchasing Green Label Products Based on Green Products and WOM. Jurnal Manajemen Maranatha, 17(2), 91-102 (In Indonesian)

Suharseno, Teguh, Riskin H. dan Dyah Ayu L.D. 2013. Effect of Consumer Dissatisfaction and Characteristics of Product Categories on Brand Switching Decision with Variety Seeking As Moderating Variables .Jurnal Buletin Studi Ekonomi. 18(2):176-182 (In Indonesian)

Thawil, Ayu N. 2014. Effects of Post-Consumption Dissatisfaction and Variety Seeking Behavior on Brand Switching GSM Mobile Phones from Blackberry to Samsung Brands.Jurnal Riset Bisnis dan Manajemen.2 (4):73-89 (In Indonesian)

Waluyo, P., Pamungkas, A., 2003, Analysis of Consumer Switching Brand Behavior in Purchasing Mobile Products in Semarang, Jurnal Bisnis dan Ekonomi: Semarang (In Indonesian)

Wangenheim FV and Bayo'n T. 2004.The effect of word of mouth on services switching: measurement and moderating variables. Eur J Market ; 38(9/10): 173-1185

Yunita, Dessy and Rosa, Aslamia (2016). Influence Analysis of Variety Seeking, Dissatisfaction and Product Unavailability to Brand Switching. Jurnal Manajemen dan Bisnis Sriwijaya. Vol 14. No. 4: 539-558 (In Indonesian) 
Zeelenberg M and Pieters R. Beyond valence in customer dissatisfaction: A review and new findings on behavioral responses to regret and disappointment in failed services. J Bus Res 2004; 57(4): 445-455

Zeithaml V, Bitner MJ and Gremler D. 2012. Services marketing, 6th ed. New York: McGraw-Hill Higher Education 